\begin{tabular}{|lll|}
\hline Diterima & $:$ & 11 Mei 2020 \\
Direvisi & $:$ & 2 Juni 2020 \\
Disetujui & $:$ & 26 Juni 2020 \\
Diterbitkan & $:$ & 27 Juni 2020 \\
\hline
\end{tabular}

\title{
STRATEGI PELATIHAN KEWIRAUSAHAAN BERBASIS PARTISIPASI UNTUK PEMBERDAYAAN WARGA BELAJAR PAKET C
}

\author{
Dayat Hidayat ${ }^{1}$, Yanti Shantini ${ }^{2}$ \& Lesi Oktiwanti ${ }^{3}$ \\ e-mail: dayat.hidayat@staff.unsika.ac.id ${ }^{1}$, yanti.shantini@upi.edu², \\ lesi.oktiwanti@unsil.ac.id ${ }^{3}$ \\ Universitas Singaperbangsa Karawang ${ }^{1}$ \\ Universitas Pendidikan Indonesia ${ }^{2}$ \\ Universitas Siliwangi ${ }^{3}$
}

Jalan HS.Ronggo Waluyo, Puseurjaya, Kec. Telukjambe Tim., Kabupaten Karawang, Jawa Barat $41361^{1}$

Jalan Dr. Setiabudi No.229, Isola, Kec. Sukasari, Kota Bandung, Jawa Barat $40154^{2}$

Jalan Siliwangi No.24, Kahuripan, Kec. Tawang, Tasikmalaya, Jawa Barat $46115^{3}$

\begin{abstract}
Abstrak: Latar belakang penelitian ini adalah; rendahnya sikap, pengetahuan, dan keterampilan fungsional warga belajar Paket $\mathrm{C}$ dalam menjalankan, mempertahankan, dan menumbuhkembangkan usahanya, rendahnya kemampuan mengakses permodalan ke beberapa bank, serta rendahnya pengetahuan dan keterampilan menerapkan teknologi. Penelitian ini berfokus pada strategi pelatihan kewirausahaan berbasis partisipatif untuk pemberdayaan warga belajar Paket $C$. Tujuan penelitian adalah mendeskripsikan data tentang implementasi dan dampak pelatihan kewirausahaan untuk pemberdayaan warga belajar Paket C. Penelitian dilakukan menggunakan pendekatan kualitatif metode studi kasus. Penelitian dilaksanakan di PKBM Ummul Yatama Kabupaten Karawang pada bulan Juli sampai dengan Desember 2019. Subyek penelitian terdiri dari pengurus, pelatih dan warga belajar Paket C. Data penelitian dikumpulkan melalui teknik observasi, wawancara dan studi dokumentasi. Hasil penelitian menyimpulkan bahwa implementasi pelatihan kewirausahaan pengolahan kerupuk kerang bagi warga belajar Paket $\mathrm{C}$ dimulai melalui tahapan perencanaan, pelaksanaan, dan penilaian. Pada tahap perencanaan pelatihan kewirauasahaan dilakukan identifikasi kebutuhan belajar, perumusan tujuan pelatihan, dan penyusunan program pelatihan. Pada pelaksanaan pelatihan warga belajar Paket $C$ diberikan materi teori dan praktek kewirausahaan. Pelaksanaan pelatihan dikolaborasikan di dalam dan luar lingkungan PKBM, mitra usaha, atau di lingkungan kerja warga belajar. Penilaian pelatihan kewirausahaan dilakukan melalui lembar observasi untuk mengevaluasi kehadiran jumlah warga belajar, kuantitas dan kualitas produksi hasil usaha pengolahan kerupuk kerang, jumlah barang yang dipasarkan, jumlah pendapatan kelompok usaha, dan besar pendapatan warga belajar Paket $C$. Dampak pelatihan kewirausahaan adalah meningkatnya pendapatan dan pemberdayaan warga belajar Paket C. Saran-saran yang dapat diberikan; ketua PKBM memberikan akses yang lebih luas untuk memberikan bantuan permodalan, meningkatkan penyaluran hasil produksi dan memberikan pelatihan kewirausahaan secara berkelanjutan.
\end{abstract}

Kata-kata Kunci: berbasis partisipasi, pelatihan kewirausahaan, pemberdayaan masyarakat

\section{PARTICIPATORY-BASED ENTREPRENEURSHIP TRAINING STRATEGY FOR EMPOWERMENT OF THE PAKET C LEARNING COMMUNITY MEMBER}

\footnotetext{
Abstract: This research was motivated by low attitudes, knowledge, and functional skills of Paket $C$ learning community members in maintaining and growing its business, low ability to access capital to several banks, and low knowledge and skills in applying technology. This research focused on participatory-based
} 
Strategi Pelatihan Kewirausahaan...

entrepreneurship training strategies for empowering of the Paket $C$ learning community members. The purpose of this study is to describe data on the implementation and impact of entrepreneurship training for empowering of the learners. The study was conducted using a qualitative approach with case study method. The study was conducted at Ummul Yatama community learning center (CLC), Karawang Regency from July to December 2019. The participants consisted of administrators, trainers and the learners of Paket $C$. The research data were collected through observation techniques, interviews and documentation. The results show that the implementation of the entrepreneurship training for processing shellfish crackers for the learners of Paket $C$ began through the stages of planning, implementation, and assessment. At the planning stage of entrepreneurship training, identification of learning needs, formulation of training objectives, and preparation of training programs were carried out. In the implementation of the training, the learners of Paket $C$ were given theoretical material and entrepreneurial practices. The training was collaborated within and outside the CLC environment, business partners, or in the work environment of learning communities. The assessment of entrepreneurship training was carried out through observation to evaluate the presence of learners, the quantity and quality of the processing of shellfish crackers product, the amount of marketed products, total groups income, and total income of each group member. This entrepreneurship training has an impact on the increase in income and empowerment of Paket $C$ learning community members. Suggestions that can be given are CLC chairperson need to provide wider access in capital assistance, increase production distribution and sustainable entrepreneurial training.

Keywords: community empowerment, entrepreneurship training, participatory based

\section{PENDAHULUAN}

Pemberdayaan masyarakat adalah topik yang paling banyak menyita perhatian pemerintah dalam upaya mengentaskan kemiskinan. Secara esensial, pemberdayaan masyarakat dilaksanakan dengan tujuan untuk meningkatkan kesejahteraan individu, keluarga, dan masyarakat secara luas. Pemberdayaan masyarakat merupakan program yang dirancang sebagai strategi peningkatan taraf kehidupan masyarakat melalui proses pengembangan kemampuan, inisiatif dan partisipasi masyarakat. Pemberdayaan masyarakat perlu melibatkan partisipasi masyarakat dalam merencanakan, melaksanakan, dan mengevaluasi sehingga program pembangunan dapat diselesaikan tepat waktu. Hal ini dikarenakan dalam merealisasikan program pemberdayaan perlu partisipasi aktif dari masyarakat (Widodo, 2018). Konsep pemberdayaan masyarakat benar-benar memiliki konsentrasi pembangunan pada tingkat grassroots. Masyarakat pada tingkat bawah diberikan rangsangan untuk dapat mendewasakan diri, membentuk kemandirian, melalui pentahapan yang disesuaikan dengan kondisi masyarakat. Pendekatan ini lebih mengutamakan kemampuan masyarakat untuk meningkatkan kemampuan teknis maupun manajerial, oleh karena itu pengorganisasian kegiatankegiatan pembangunan diprakarsai oleh masyarakat. (Sulistiyani, 2017).

Pemberdayaan dalam bidang pendidikan, berarti meningkatkan kemampuan dan keberanian untuk melakukan perubahan sosial, ekonomi, politik, maupun budaya untuk terus menerus memperbaiki kehidupan.
Pemberdayaan bidang pendidikan merupakan praktek pembebasan diri dari ketidaktahuan, tekanan-tekanan dan lain-lain hal yang membelenggu seseorang dan atau kelompok masyarakat untuk memperbaiki kehidupannya (Freire, 1973, dalam Mardikanto \& Soebiato, 2015). Salah satu strategi pemberdayaan masyarakat dalam bidang pendidikan yang dilakukan adalah melalui pelatihan pengembangan kewirausahaan pada program pendidikan masyarakat. Pemberdayaan masyarakat dalam konteks pendidikan masyarakat, lebih diutamakan pada sasaran utama yaitu terjadinya perubahan berpikir, bersikap dan berperilaku masyarakat menjadi rasional, dari perilaku malas menjadi rajin, dari sikap ketergantungan menjadi mandiri dalam aspek sosial dan ekomomi. Salah satu upaya pemberdayaan masyarakat bidang pendidikan masyarakat dapat dilaksanakan melalui program pelatihan kewirausahaan. Pelatihan merupakan proses pengalaman belajar yang sengaja dirancang untuk membantu peserta didik dalam menguasai kemampuan keterampilan yang tidak dikuasai sebelumnya. Pada intinya, pelatihan merupakan serangkaian proses pembelajaran yang diberikan kepada peserta didik. Pelatihan merupakan disposisi perubahan pengetahuan, sikap dan keterampilan tertentu peserta didik. Proses pelatihan dilaksanakan agar peserta didik dapat menyesuaikan diri dengan perubahan kemampuan yang menuntut pekerjaannya secara efektif dan efisien. Pelatihan adalah proses pembelajaran yang mengutamakan pada peningkatan aspek keterampilan peserta didik. Dessler (2013) 
mengemukakan training refers to the activities which provide new or current employees the skills which are needed to perform their jobs. The purpose of training is to emphasize the growth and developments of personnel which aim at assisting them have adequate knowledge and skills to perform their jobs more efficiently (Noe, 2010). Dick, et al. (2015) mendefinisikan pelatihan sebagai: "... A prespecified and planned experience that enable a person to do something that he or she could not do before".

Pelatihan kewirausahaan pada jalur pendidikan nonformal dilaksanakan dalam upaya mengatasi kesulitan ekonomi yang menjadi masalah mendasar kehidupan masyarakat, khususnya di daerah perdesaan. Pelatihan kewirausahaan adalah program pemberdayaan ekonomi masyarakat yang bertujuan membangun kemampuan berpikir kritis warga belajar untuk mengidentifikasi dan menganalisis potensi sosial, ekonomi dan politik yang dihadapinya, serta mampu meningkatkan kompetensi keterampilannya untuk memperbaiki taraf kehidupannya. Peran pendidik masyarakat sangat penting dalam meningkatkan sikap kemandirian berwirausaha warga belajar program pendidikan nonformal. Pelatihan kewirausahaan dilaksanakan untuk menumbuhkan, mengembangkan, mendampingi dan membina kewirausahaan masyarakat melalui dua pendekatan. Pertama, materi kewirausahaan diintegrasikan ke dalam kurikulum satuan dan jenis program pendidikan nonformal. Kedua, materi kewirausahaan menjadi program tersendiri pendidikan kewirausahaan masyarakat yang dilaksanakan di jalur pendidikan nonformal. Pada pendekatan pertama, materi kewirausahaan dijadikan materi pokok atau tambahan yang dilaksanakan pada satuan jalur pendidikan nonformal seperti lembaga pelatihan, lembaga kursus, kelompok belajar, Pusat Kegiatan Belajar Masyarakat (PKBM) dan satuan pendidikan sejenis lainnya, seperti penyuluhan dan pusat-pusat magang. Selain itu, materi kewirausahaan diintegrasikan pula ke dalam jenis pendidikan umum, keagamaan, kedinasan, jabatan kerja, dan kejuruan/keterampilan. Kedua pendekatan pelatihan kewirausahaan masyarakat ini dikembangkan sebagai bagian program pemberdayaan ekonomi kerakyatan. Pendekatan ini bermanfaat untuk meningkatkan kemampuan mengelola program kewirausahaan masyarakat dan menguatkan lembaga perekonomian masyarakat (Kemendikbud, 2016).

Program pelatihan kewirausahaan bertujuan memberikan penyadaran berbagai elemen dan lapisan masyarakat menentukan orientasi kebutuhan ekonomi dan sinergitas partisipasinya mewujudkan pemberdayaan masyarakat. Pelatihan kewirausahaan dilaksanakan menggunakan pendekatan keterampilan fungsional atau kecakapan hidup (life skills) yang mendukung fungsi-fungsi ekonomi masyarakat. Dengan demikian para pendidik masyarakat dituntut memiliki kompetensi yang mampu mengelola program pelatihan kewirausahaan. Tutor sebagai salah satu pendidik masyarakat harus memiliki kompetensi pelatihan dan kewirausahaan agar mampu membina sikap, pengetahuan dan keterampilan warga belajar. Tutor memiliki peran dan fungsi menumbuhkan, mendorong, membangkitkan dan membangun pola pikir, meningkatkan sikap perilaku, pengetahuan dan keterampilan kewirausahaan masyarakat, seperti pada program Kelompok Belajar Paket C. Melalui pengembangan kewirausahaan masyarakat, PKBM memiliki unit-unit bisnis yang dapat mendukung kehidupan dan kesejahteraan PKBM dan pemberdayaan warga belajar pendidikan nonformal (Rahma, dkk., 2019).

Program pelatihan kewirausahaan bertujuan menumbuhkembangkan perilaku kewirausahaan warga belajar Paket $C$ yang tercermin dalam kepribadian yang inovatif, kreatif, disiplin, percaya diri, berani menghadapi resiko, memiliki motivasi dan kemauan yang kuat mengembangkan usahanya. Program Paket $C$ berbasis kewirausahaan secara khusus bertujuan meningkatkan pendapatan ekonomi yang berdampak terhadap pemberdayaan ekonomi warga belajar dan masyarakat. Setelah warga belajar mengikuti pelatihan kewirausahaan dapat meningkatkan kemandirian berwirausaha. Kemandirian ekonomi tersebut tercermin pada perubahan taraf hidup yang ditandai oleh meningkatnya kesempatan memperoleh pekerjaan, keterampilan berwirausaha, pendapatan keluarga, kesehatan, dan penampilan diri. Program Paket $\mathrm{C}$ merupakan jenis pendidikan kesetaraan berbasis keterampilan fungsional atau keterampilan berwirausaha. Program Paket $C$ berbasis kewirausahaan ini hakekatnya bertujuan untuk menjawab permasalahan warga belajar Paket C di PKBM Ummul Yatama desa Mekarmaya kecamatan Cilamawa Wetan Kabupaten Karawang. Program Paket C di PKBM Ummul Yatama disinergikan dengan pelatihan kewirausahaan berbasis potensi lokal sebagai bentuk pemberdayaan ekonomi keluarga warga belajar. Pengelola PKBM Ummul Yatama berupaya meningkatkan ekonomi warga belajar Paket $C$ sesuai potensi lokal berupa hasil olahan kerang, melalui pelatihan kewirausahaan, sehingga dapat mendorong kemajuan ekonomi masyarakat. 
Program Paket $\mathrm{C}$ di PKBM Ummul Yatama secara geografis berada di daerah desa Mekarmaya kecamatan Cilamaya Wetan Kabupaten Karawang. Masyarakatnya sebagaian besar (79\%) bermatapencaharian sebagai buruh tani dan sebagian kecil lainnya $(21 \%)$ sebagai wiraswasta, nelayan dan matapencaharian lainnya. Kondisi ini penyebabkan masyarakat tertinggal dalam pendidikan, kesehatan dan daya beli masyarakat. Berdasarkan hasil identifikasi yang telah dilakukan dapat dirumuskan masalah penelitian yaitu tentang implementasi pelatihan kewirausahaan untuk pemberdayaan warga belajar Paket $C$ di PKBM Ummmul Yatama. Adapun tujuan dalam penelitian ini adalah untuk mendeskripsikan 1) implementasi pelatihan kewirausahaan, dan 2) dampak pelatihan kewirausahaan untuk pemberdayaan warga belajar Paket C di PKBM Ummul Yatama desa Mekarmaya kecamatan Cilamaya Wetan Kabupaten Karawang.

Manfaat penelitian ini adalah untuk memberikan; 1) masukan bagi pengembangan teori pelatihan kewirausahaan dan pemberdayaan masyarakat, 2) masukan bagi pengurus agar pelatihan kewirausahaan di PKBM Ummul Yatama berjalan baik dan mencapai hasil yang lebih optimal, 3) pengalaman praktis dalam mengembangkan kemampuan pengelola programprogram Pendidikan Nonformal dan Imformal (PNFI) yang lebih luas sesuai dengan keberagaman program dan sasaran peserta didiknya.

Pemberdayaan masyarakat melalui pelatihan kewirausahaan bertujuan menambah kemampuan dan wawasan warga belajar Paket $C$ untuk mengembangkan rintisan usaha. Aspek penting dalam suatu pemberdayaan masyarakat adalah program yang disusun sendiri oleh masyarakat, mampu menjawab kebutuhan masyarakat, mendukung keterlibatan kaum miskin dan kelompok yang terpinggirkan lainnya, dibangun dari sumberdaya lokal, sensitive terhadap nilai-nilai budaya lokal, memperhatikan dampak lingkungan, tidak menciptakan ketergantungan, berbagai pihak terkait terlibat (instansi pemerintah, lembaga penelitian, perguruan tinggi. LSM, swasta dan pihak lainnya), serta secara berkelanjutan. (Mardikanto \& Soebiato, 2015). Melalui pelatihan kewirausahaan yang dilaksanakan secara konsisten, masyarakat daerah dapat menjadi aset sumber daya manusia bagi pengembangan rintisan usaha. Dengan demikian, pelatihan dan pengembangan kewirausahaan dapat memberikan manfaat bagi masyarakat dalam meningkatkan taraf kesejahteraannya. Selain itu, pemberdayaan masyarakat melalui pelatihan kewirausahaan menjadi salah satu solusi pemecahan berbagai masalah sosial yang terjadi di masyarakat, termasuk di PKBM Ummul Yatama. Pelatihan kewirausahaan berbasis potensi lokal di PKBM Ummul Yatama merupakan proses pemberdayaan yang dapat dikembangkan untuk peningkatan kesejahteraan perekonomian masyarakat. Tujuan pelatihan kewirausahaan berbasis potensi lokal dilaksanakan untuk mendorong terwujudnya kemandirian ekonomi masyarakat melalui pengembangan potensi yang dimiliki masyarakat di sekitar PKBM Ummul Yatama.

Pelatihan merupakan proses pengalaman belajar yang sengaja dirancang untuk membantu peserta didik dalam menguasai kemampuan keterampilan yang tidak dikuasai sebelumnya. Pada intinya, pelatihan merupakan serangkaian proses pembelajaran yang diberikan kepada peserta didik. Pelatihan merupakan disposisi perubahan pengetahuan, sikap dan keterampilan tertentu peserta didik. Proses pelatihan dilaksanakan agar peserta didik dapat menyesuaikan diri dengan perubahan kemampuan yang menuntut pekerjaannya secara efektif dan efisien. Pada prinsipnya kegiatan pelatihan dilakukan karena adanya kebutuhan pada suatu organisasi. Suatu lembaga meyakini bahwa pada prinsipnya hasil pelatihan harus membuat peserta didiknya menjadi lebih pandai dan mampu melaksanakan pekerjaannya. Tujuan pelatihan lebih mengenalkan tingkah laku baru atau mengubah tingkah laku yang ada sehingga tercipta tingkah laku yang baru. Pelatihan dirancang untuk memperbaiki performa peserta didik (Nadler, 2012). Stategi pemberdayaan masyarakat melalui pelatihan kewirausahaan di PKBM Ummul Yatama memberikan hal-hal baru yang kreatif dalam membuka lapangan usaha pada warga belajar Paket $C$ dalam berusaha sebagai penghasilan, meningkatkan pendapatan keluarga dan peningkatan kemampuan diri melalui kemampuan pengetahuan serta peningkatan keterampilan produksi potensi lokal dan budaya kerja yang mengarah kepada Good Manufacture Production (GMP).

Beberapa hal yang menjadi perhatian di lingkungan PKBM Ummul Yatama adalah warga belajar Paket $C$ yang didominasi golongan yang kurang mampu. Kendala utama yang menjadi permasalahan belum terciptanya wirausahawan handal di PKBM Ummul Yatama, antara lain: 1) sikap, pengetahuan, dan keterampilan fungsional warga belajar Paket C dalam menjalankan, mempertahankan, dan menumbuhkembangkan usahanya masih rendah, dan 2) kemampuan mengakses permodalan ke beberapa Bank masih lemah, 3) kemampuan pengetahuan dan keterampilan menerapkan teknologi masih 
terbatas. Kondisi ini yang mendorong pengurus PKBM Ummul Yatama mengkolaborasikan desain pelatihan kewirausahaan yang terintegrasi pemanfaatan dan pendayagunaan potensi lokal/lingkungan). Tujuannya adalah menumbuhkan dan mengembangkan sikap, pengetahuan dan keterampilan usaha mikro warga belajar melalui pelatihan kewirausahaan yang bersifat integratif, inovatif, motivatif, kreatif, produktif, dan rekreatif sehingga mereka memiliki kemampuan mempertahankan dan mengembangkan usahanya. Selain itu, pelatihan kewirausahaan ini mengelaborasi pemanfaatan dan pendayagunaan potensi lokal yang bersumber dari lingkungan alam dan masyarakat atau sejenisnya secara bergulir dan bergantian untuk mendukung usaha yang dijalankan warga belajar Paket C di PKBM Ummul Yatama.

Sebagai pelaku ekonomi kewirausahaan adalah pemanfaatan dan penciptaan peluang dalam perubahan yang terjadi seperti teknologi, preferensi konsumen dan norma-norma sosial untuk kemajuan ekonomi di masyarakat. Proses kewirausahaan berusaha mengembangkan hal-hal baru dalam mengembangkan usaha berdasarkan potensi yang dimiliki masyarakat. Hisrich-Peters (2011) berpendapat bahwa enterpreneurship is the process of creating something different with value by devoting the necessary time and effort, assuming the accompanying financial, psyhic, and social risk, and receiving the resulting rewards of monetary and personal satisfaction and independence. Druker, P. (2015) defines entrepreneurship "ability to create the new and different". Kewirausahaan dapat diartikan sebagai kemampuan seseorang menciptakan hal-hal yang baru dan berbeda. Kewirausahaan merupakan suatu proses kebebasan menciptakan sesuatu yang baru disertai modal dan resiko serta menerima balas jasa dan kepuasan serta kebebasan. Konsep inovasi memberikan pengaruh besar terhadap keberhasilan proses kewirausahaan masyarakat dalam mengembangkan potensi lokal wilayahnya. Sikap kreatif dan inovatif menjadi aspek yang sangat penting dalam mengembangkan kewirausahaan yang berbasis pada potensi lokal. Innovation plays a pivotal role in business competition. While Schumpeter introduces a term of 'creative destruction' to point out the role of agents in economic development (Borchert \& Cardozo, 2010), the process of entrepreneurship in developing countries tends to refer to 'creative imitation' due to imitation process from other side of the world with different levels of adhocracy (Naranjo-Valencia et al., 2011). Pelatihan kewirausahaan merupakan sarana peningkatan sikap, pengetahuan dan keterampilan agar warga belajar Paket $\mathrm{C}$ mampu memberdayakan dirinya agar mengolah hasil produksi kerupuk kerang, sehingga mendapatkan penghasilan yang layak untuk memenuhi kehidupan dirinya dan keluarganya.

\section{METODE PENELITIAN}

Pendekatan penelitian yang digunakan adalah kualitatif dengan metode studi kasus. Pendekatan kualitatif ini digunakan untuk menekankan suatu gambaran yang kompleks dan holistik, suatu rujukan pada naratif yang kompleks yang mengajak pembaca ke dalam dimensi jamak dari sebuah masalah atau isu dan menyajikannya dalam semua kompleksitasnya (Creswell, 2010). Metode studi kasus yang digunakan untuk memahami secara mendalam situasi dan kondisi faktual saat ini tentang obyek penelitian. Melalui studi kasus ini peneliti menggambarkan dan menganalisis data secara rinci tentang implementasi pelatihan kewirausahaan dan dampaknya terhadap pemberdayaan warga belajar Paket C di PKBM Ummul Yatama. Metode studi kasus ini digunakan karena lebih cocok bila pokok pertanyaan suatu penelitian yang berkenaan dengan "how" atau "why", bila peneliti hanya memiliki sedikit peluang untuk mengontrol peristiwaperistiwa yang diteliti, dan bilamana fokus penelitiannya terletak pada fenomena kontemporer (masa kini) di dalam konteks kehidupan nyata. (Yin, 2012).
Subjek dalam penelitian tentang pelatihan kewirausahaan di PKBM Ummul Yatama ini sebanyak tujuh orang yang terdiri dari lima orang warga belajar Paket C, satu orang pelatih kewirausahaan dan satu orang pengurus PKBM Ummmul Yatama. Subyek penelitian ini tidak banyak karena dilakukan secara purposif(sesuai dengan tujuan). Hal ini merujuk kepada pendapat Nasution (1988) bahwa "metode naturalistik tidak menggunakan sampling random atau acak, dan tidak pula menggunakan populasi sampel yang banyak". Dalam penelitian kualitatif tidak membutuhkan populasi dan sampel yang banyak. Subyek penelitian biasanya sedikit dan dipilih sesuai tujuan penelitian. Jumlah subyek penelitian tidak ditentukan secara ketat, tetapi tergantung kepada tercapainya redudancy, ketuntasan atau kejenuhan data.

Pengumpulan data dalam penelitian ini menggunakan teknik; 1) observasi kualitatif yang bertujuan mengamati langsung perilaku dan aktivitasaktivitas partisipan di lokasi penelitian. Peneliti merekam/mencatat hasil pengamatan tentang 
perencanaan, pelaksanaan, penilaian, dan dampak pelatihan kewirausahaan terhadap pemberdayaan warga belajar Paket C di PKBM Ummul Yatama, 2) wawancara yang digunakan untuk melakukan tanyajawab dengan partisipan tentang bagaimana teknik yang digunakan pada saat mengidentifikasi kebutuhan pelatihan, cara merumuskan tujuan pelatihan kewirausahaan, cara menyusun kurikulum dan materi pelatihan kewirausahaan di PKBM Ummul Yatama. Wawancara juga digunakan untuk mengumpulkan data terkait dengan proses selama pelatihan kewirausahaan berlangsung dan bagaimana pelatihan memberikan dampak terhadap pemberdayaan ekonomi warga belajar Paket $\mathrm{C}$, dan 3) selama proses penelitian, peneliti juga mengumpulkan studi dokumentasi kualitatif yang menunjang kelengkapan data penelitian seperti; profil PKBM, data pribadi warga belajar Paket $\mathrm{C}$, jumlah pendapatan atau penghasilan dan data-data lainnya yang berkaitan dengan program pelatihan kewirausahaan di PKBM Ummul Yatama.

Langkah penelitian dilakukan melalui tahapan, yaitu: 1) orientasi untuk memperoleh gambaran yang jelas dan lengkap tentang fokus permasalahan yang akan diteliti, 2) ekplorasi untuk menggali data dan informasi sesuai tujuan penelitian tentang pelatihan kewirausahaan di PKBM Ummul Yatama, dan 3) member check untuk melakukan pengecekan kebenaran dari informasi yang diperilah hasil wawancara tentang pelatihan kewirausahaan di PKBM Ummul Yatama (Nasution, 1988). Setelah data terkumpul melalui teknik pengumpulan data dan tahapan penelitian yang telah dilakukan, peneliti menganalisis data melalui langkah-langkah: 1) mengolah dan mempersiapkan data, yang melibatkan transkripsi wawancara, 2) membaca keseluruhan data, yang membangun general sense atas informasi yang diperoleh dan merepleksikan maknanya secara keseluruhan, 3) menganalisis lebih detail dengan mencoding data, yang merupakan proses mengolah materi/informasi menjadi segmen-segmen tulisan sebelum memaknainya, 4) menerapkan proses coding untuk mendeskripsikan seting, orang-orang, kategori-kategori, dan tema-tema yang dianalisis, 5) menunjukkan deskripsi/gambaran dan tema-tema yang akan disajikan kembali dalam narasi/laporan kualitatif, dan 6) menginterpretasi atau memaknai data (Creswell, 2010).

\section{HASIL DAN PEMBAHASAN}

\section{Hasil}

\section{Implementasi Pelatihan Kewirausahaan}

Ummul Yatama adalah PKBM berdiri pada tanggal 1 Juli 2000 Dusun Kertasari RT.12/RW.05 Desa Mekarmaya Kecamatan Cilamaya Wetan Kabupaten Karawang. Status kepemilikan PKBM Ummul Yatama adalah yayasan Ummul Yatama dengan status kelembagaan milik swasta. Bangunan yang digunakan dalam melaksanakan programmnya adalah milik sendiri. Program yang berlangsung di PKBM Ummul Yatama adalah; 1) Program Kesetaraan Kejar Paket A, B dan C, 2) Program Life Skills (Pembuatan Aneka Kerupuk Kerang dan Ikan), dan 3) Program Keksaraan Fungsional (KF). Adapun yang menjadi program unggulan di PKBM Ummul Yatama adalah pengembangan kewirausahaan pembuatan kerupuk kerang yang diintegrasikan dengan program kesetaraan Paket $\mathrm{C}$.

Program pelatihan kewirausahaan pengolahan kerupuk kerang yang dilaksanakan di PKBM Ummul Yatama bertujuan untuk memberdayakan masyarakat di bidang pendidikan dan pengembangan kewirausahaan warga belajar Paket C. Berdasarkan hasil temuan penelitian tentang pelatihan kewirausahaan di PKBM Ummul Yatama, disusun melalui tahapan perencanaan, pelaksanaan, dan penilaian. Pada tahap perencanaan pelatihan dilakukan identifikasi kebutuhan pelatihan, perumusan tujuan pelatihan dan penyusunan program pelatihan kewirausahaan. Pada tahap identifikasi kebutuhan dan perumusan tujuan pelatihan diperoleh data bahwa sesuai dengan kebutuhan belajar dan potensi yang tersedia yaitu tentang pengolahan kerupuk kerang. Pada tahap penyusunan program pelatihan didesain program pelatihan kewirausahaan terdiri dari kurikulum, bahan/materi, metode, dan penilaian pelatihan. Kurikulum pelatihan kewirausahaan pengolahan kerupuk dari kerang dikembangkan berdasarkan kepada; tujuan, materi, metode, dan penilaian pelatihan. Tujuan pelatihan kewirausahaan yang dimaksudkan disediakan atau disiapkan untuk memberi kesempatan kepada warga belajar Paket C mengikuti pelatihan kewirausahaan pengolahan kerupuk kerang. Dalam prakteknya, materi pelatihan kewirausahaan diimplementasikan untuk mencapai kompetensi kewirausahaan yang terdiri dari; 
Tabel 1.

Materi Pelatihan Kewirausahaan Pengolahan Kerupuk Kerang di PKBM Ummul Yatama

\begin{tabular}{llc}
\hline No & \multicolumn{1}{c}{ Materi } & \multicolumn{1}{c}{ JP } \\
(1JP @60')
\end{tabular}

Sumber: PKBM Ummul Yatama

Materi pelatihan merupakan bagian terpenting dalam menyusun bahan pelatihan kewirausahaan untuk warga belajar Paket $\mathrm{C}$ agar dapat mempraktekkan kompetensi kewirausahaan dalam menjalankan usahanya. Materi pelatihan kewirausahaan disusun sebagai 1) bahan pelatihan yang sesuai dengan kompetensi kewirausahaan, sesuai dengan pencapaian tujuan kompetensi kewirausahaan, dan 3) sebagai arah untuk menghasilkan UMKM warga belajar Paket $\mathrm{C}$.

Metode pelatihan kewirausahaan ditentukan agar proses pelatihan dapat berjalan dengan baik. Metode pelatihan merupakan cara memproses pelatihan agar warga belajar berinteraksi aktif sehingga terjadi perubahan pada dirinya sesuai tujuan pelatihan. Dengan demikian metode pelatihan berfungsi sebagai penuntun penyampaian materi, pembangkit perhatian dan minat warga belajar, pencipta peluang saling berinteraksi antar komponen pelatihan, memproses perubahan diri warga belajar, dan menciptakan iklim pelatihan yang kondusif. Pertimbangan yang diperhatikan pada saat menentukan metode pelatihan antara lain adalah, tujuan pelatihan, materi/bahan pelatihan, karakteristik warga belajar, waktu dan lama berlatih, fasilitas pelatihan, kemampuan pelatih dan lingkungan pelatihan. Beberapa metode yang digunakan pada pelatihan kewirausahaan di PKBM
Ummul Yatama adalah, ceramah, pemasaran, tanya jawab, curah pendapat, diskusi, kerja kelompok, demontrasi, praktek lapangan, penugasan, dan karyawisata. 1) Pemilihan metode pelatihan bertujuan agar pelatih memahami dan terampil mengorganisir kelompok belajar Paket $\mathrm{C}$ ke arah tujuan pelatihan. 2) Pelatih memiliki kewajiban mengetahui, memahami dan mempraktekkan beberapa metode sehingga dapat memilih dan menentukan cara yang tepat sesuai bahan/isi materi pelatihan yang akan dilatihkan. 3) Apabila pelatih hanya menggunakan satu macam metode saja maka pelatihan berlangsung kaku dan membosankan. Organisasi pelatihan adalah pentatalaksanaan kurikulum pelatihan agar mudah menjabarkan dan melaksanakan program pelatihan kewirausahaan.

Penilaian merupakan komponen kurikulum pelatihan, karena merupakan salah satu komponen pelaksanaan program pelatihan kewirausahaan di PKBM Ummul Yatama. Hasil informasi penilaian dapat dijadikan tolak ukur dan kebijakan tentang kurikulum dan pencapaian tujuan pelatihan kewirausahaan. Peningkatan usaha olahan makanan belum banyak dilakukan sehingga perlu adanya diversifikasi bentuk produk olahan makanan kecil sesuai dengan potensi lingkungan. Kerupuk kerang merupakan salah satu produk olahan makanan dari kerang yang mulai dikembangkan di PKBM Ummul Yatama. Kerupuk kerang adalah makanan kering yang dibuat dari bahan dasar olahan kerang dicampur dengan tepung yang diproses dengan menggoreng atau memanggangnya sebelum disajikan. Kerupuk kerang tersebut dikenal sebagai teman makan nasi ataupun sebagai makanan kecil (snack).

Tujuan pelatihan kewirausahaan adalah meningkatkan kompetensi kewirausahaan warga belajar Paket $\mathrm{C}$ sehingga dapat menjalankan usahanya yang berbasis pada potensi lokal dengan memaksimalkan sumber daya manusia dan daya alam di sekitarnya. Dalam operasionalisasinya, pelatihan kewirausahaan dilaksanakan untuk meningkatkan kompetensi berwirausaha 20 orang warga belajar Paket C. 20 warga belajar tersebut adalah mereka yang berhasil diseleksi mengikuti pelatihan kewirausahaan. Pengelola PKBM membuka peluang dan kesempatan secara terbuka dan seluasluasnya kepada warga belajar untuk mengolah dan memproduksi olahan makanan lokal, seperti kerupuk kerang sebagai usaha ekonomi masyarakat kecil dan menengah. Tujuan pelatihan pengolahan kerupuk kerang bagi warga belajar Paket $C$ tersebut adalah menumbuhkan dan mengembangkan sikap mental, 
pengetahuan dan keterampilan usaha mikro warga belajar melalui pelatihan kewirausahaan yang bersifat integratif, inovatif, motivatif, kreatif, produktif, dan rekreatif sehingga mereka memiliki kemampuan mempertahankan dan mengembangkan usahanya.

Program Paket $\mathrm{C}$ yang diintegrasikan dengan pelatihan kewirausahaan yang berbasis potensi lokal dilaksanakan selama 6 bulan; pelatihan selama 3 bulan, Juli sampai September 2019, dan melaksanakan pendampingan usaha kepada warga belajar dilaksanakan bulan Oktober sampai Desember 2019. Tahap pelatihan kewirausahaan dilaksanakan seminggu 3 kali selama 68 jam pelatihan. Sedangkan pada tahap pendampingan, pengurus PKBM melaksanakan monitoring dan evaluasi seminggu sekali ke tempat usaha masing-masing kelompok usaha warga belajar. Pelatihan kewirausahaan ini merupakan wujud nyata pengembangan ekonomi kerakyatan yang diberikan kepada warga belajar Paket $C$ di PKBM Ummul Yatama. Program ini merupakan upaya pemberdayaan ekonomi keluarga yang dilaksanakan mulai dari rekrutmen warga belajar dalam membentuk kelompok usaha, proses pelatihan kewirausahaan, memfasilitasi ijin halal hasil produksi olahan kerupuk kerang dari MUI, ijin kesehatan termasuk hak paten dari BPOM dan Dinas Kesehatan. Model pelatihan kewirausahaan ini diharapkan dapat diterapkan di PKBM Ummul Yatama sebagai pengembangan model kewirausahaan masyarakat. Pada prakteknya, warga belajar Paket $\mathrm{C}$ melakukan usaha olahan kerupuk kerang dan olahan makanan lokal lainnya yang berbahan baku hasil alam sekitarnya. Pada prinsipnya pengembangan kewirausanaan di PKBM Ummul Yatama melalui pengembangan usaha yang berbasis pada potensi lokal.

Berdasarkan hasil wawancara dengan pengurus PKBM Ummul Yatama diperoleh data bahwa pada tahap perencanaan pelatihan kewirausahaan, pelatih dan pengurus melakukan kegiatan identifikasi permasalahan yang dirasakan warga belajar Paket $\mathrm{C}$, materi atau bahan pelatihan yang dibutuhkan dan berbagai potensi sumber daya lokal yang dapat dikembangkan untuk peluang usaha. Pelatih kewirausahaan melakukan komunikasi secara intens dan memotivasi warga belajar untuk memperoleh kejelasan dan kepastian bahwa warga belajar sungguh-sungguh mengikuti pelatihan kewirausahaan. Kegiatan identifikasi dilakukan untuk mengetahui: 1) latar belakang warga belajar mengikuti Paket C, 2) berbagai potensi yang dimiliki warga belajar untuk mengembangkan usaha selama mengikuti proses pelatihan, 3) latar belakang kehidupan warga belajar di rumah dan lingkungan masyarakatnya, 4) situasi dan kondisi lingkungan warga belajar tinggal dan bekerja/ berusaha, dan 5) kebiasaan-kebiasaan, aturan, dan nilai-nilai yang berlaku di lingkungan warga belajar. Kegiatan identifikasi dilakukan untuk membantu menganalisis dan memecahkan persoalan-persoalan sebagai dasar penyusunan desain dan tema-tema pelatihan kewirausahaan yang cocok sesuai dengan potensi lokal. Gagasan pengembangan kewirausahaan disesuaikan dengan potensi, kebiasaan, aturan, dan nilai-nilai budaya lokal yang berlaku di masyarakat.

Pada tahap pelaksanaan pelatihan kewirausahaan pengolahan kerupuk kerang warga belajar Paket $\mathrm{C}$ diberikan materi melalui pola umum yaitu: 1) materi pelatihan kewirausahaan dengan komposisi; 30\% teori, $70 \%$ praktik dan implementasi, 2) teori kewirausahaan diberikan di kelas, 3) praktik kewirausahaan dan implementasi dilaksanakan kewirausahaan sebagian besar di luar kelas atau ruangan praktek lain di lingkungan PKBM, dan di luar jam pelatihan teori. Frekuensi pertemuan sesuai jenis praktikum yang telah terjadwal sejak awal, 4) implementasi seluruhnya dilakukan di luar lingkungan PKBM, mitra usaha, atau di lingkungan kerja masingmasing warga belajar, dan 5) pola pendampingan dengan mitra kerja dan mitra usaha PKBM sebagai sarana konsultasi bagi warga belajar. Strategi yang digunakan dalam pelatihan kewirausahaan di PKBM Ummul Yatama adalah sebagai berikut;

Tabel 2.

Strategi Pelatihan Kewirausahaan Pengolahan Kerupuk Kerang di PKBM Ummul Yatama

\begin{tabular}{|c|c|c|}
\hline No & Strategi & Tujuan \\
\hline 1. & $\begin{array}{l}\text { Strategi } \\
\text { produksi }\end{array}$ & $\begin{array}{l}\text { untuk menentukan jenis dan hasil } \\
\text { produksi usaha kerupuk kerang yang } \\
\text { dilaksanakan dan dikembangkan } \\
\text { sebagai usaha warga belajar }\end{array}$ \\
\hline 2. & $\begin{array}{l}\text { Strategi } \\
\text { proses }\end{array}$ & $\begin{array}{l}\text { untuk penyusunan desain program } \\
\text { dan materi sehingga pelatihan } \\
\text { kewirausahaan pengolahan kerupuk } \\
\text { kerang dapat berjalan efektif dan efisien } \\
\text { dan memperoleh hasil yang maksimal }\end{array}$ \\
\hline 3. & $\begin{array}{l}\text { Strategi } \\
\text { lokasi }\end{array}$ & $\begin{array}{l}\text { untuk menentukan tempat pelatihan dan } \\
\text { usaha pengolahan kerupuk kerang yang } \\
\text { dilaksanakan sesuai kondisi tempat } \\
\text { tinggal warga belajar }\end{array}$ \\
\hline 4. & $\begin{array}{l}\text { Strategi } \\
\text { sumber } \\
\text { daya } \\
\text { manusia }\end{array}$ & $\begin{array}{l}\text { untuk mengidentifikasi sumber daya } \\
\text { potensi manusia dan alam yang } \\
\text { diperlukan dalam pengembangan usaha } \\
\text { pengolahan kerupuk kerang oleh warga } \\
\text { belajar di sekitar lokasi PKBM }\end{array}$ \\
\hline
\end{tabular}

Sumber: PKBM Ummul Yatama

Penyusunan jadwal disepakati bersama antara pengurus PKBM, pelatih dan warga belajar dengan 
mempertimbangkan kesiapan belajar dan waktu luangnya.

Selanjutnya pada tahap penilaian pelatihan kewirausahaan pengolahan kerupuk kerang di PKBM Ummul Yatama dilakukan dengan memonitor dan mengevaluasi indikator keberhasilan yang telah ditetapkan dalam perencanaan program usaha melalui lembar observasi. Lembar penilaian observasi tersebut terdiri dari kehadiran jumlah warga belajar Paket $\mathrm{C}$, kuantitas dan kualitas produksi hasil usaha pengolahan kerupuk kerang, jumlah pemasaran, jumlah pendapatan kelompok usaha, dan besar pendapatan yang diterima warga belajar Paket $\mathrm{C}$.

\section{Dampak Implementasi Pelatihan Kewirausahaan}

Peningkatan kompetensi kewirausahaan warga belajar Paket $\mathrm{C}$ yang ditandai bertambahnya sikap, pengetahuan, dan keterampilan kewirausahaan, sikap keberanian, dan kemandirian baik secara perorangan ataupun sebagai bagian dari rintisan inkubator bisnis yang dikembangkan PKBM. Pelatihan kewirausahaan ini diharapkan memberikan penguatan pada pemberdayaan ekonomi masyarakat. Dampak pelatihan kewirausahaan ini merupakan proses pemberdayaan masyarakat pada aspek peningkatan ekonomi keluarga warga belajar Paket C. Produk usaha olahan kerupuk kerang PKBM Ummul Yatama sudah mendapatkan legalitas produk yaitu dengan mendapatkan ijin kesehatan, sertifikat halal dari MUI, barcode, SIUP, dan TDP dari BPMPT, sertifikat pendidikan, dan pelatihan keselamatan kerja dari Dinas Tenaga Kerja dan Transmigrasi Kabupaten Karawang. Untuk mendapatkan legalitas produk dan ijin dari Dinas Kesehatan dan sertifikat halal dari MUI selama kurang lebih 1 (satu) bulan. Untuk mendapatkan barcode, SIUP, dan TDP dari BPMPT kurang lebih selama kurang lebih 2 (dua) bulan sejak hasil produksi diajukan. Untuk mendapatkan sertifikat pendidikan dan pelatihan keselamatan kerja dari Dinas Tenaga Kerja dan Transmigrasi Kabupaten Karawang diberikan setelah selesai 6 (enam) bulan mengikuti pelatihan kewirausahaan di PKBM Ummul Yatama.

Langkah selanjutnya yang dilakukan pengurus PKBM adalah; 1) memasarkan hasil olahan kerupuk kerang ke tingkat yang lebih luas agar dikenal sebagai produk potensi lokal khas PKBM Ummul Yatama desa Mekarmaya sebagai salah satu produk unggulan dengan memasarkan ke toko-toko atau warungwarung oleh-oleh di sekitar kecamatan Cilamaya Wetan dan outlet oleh-oleh makanan khas Kabupaten Karawang, 2) menawarkan dan menjadi langganan beberapa rumah makan di Kabupaten Karawang, dan
3) memasarkan hasil olahan kerupuk kerang melalui media online, yaitu media facebook masing-masing anggota kelompok usaha warga belajar Paket $\mathrm{C}$ di PKBM Ummul Yatama.

Warga belajar dan pengurus PKBM Ummul Yatama mengemukakan bahwa dampak dan manfaat pelatihan kewirausahaan kerupuk kerang terhadap warga belajar Paket $\mathrm{C}$ adalah: 1) terbukanya peluang usaha produksi olahan kerupuk kerang sehingga mendapatkan penghasilan, 2) meningkatkan harga jual bahan baku kerupuk kerang dari warga belajar kepada pengepul lain, 3) meningkatkan pendapatan warga belajar yang mencapai Rp. 500.000-800.000 perbulan, 4) meningkatnya kapasitas diri melalui kemampuan kewirausahaan serta peningkatan keterampilan produksi dan budaya kerja yang baik. Dengan demikian pelatihan kewirausahaan pengolahan kerupuk kerang telah memberikan dampak terhadap peningkatan pemberdayaan ekonomi warga belajar Paket C di PKBM Ummul Yatama.

\section{Pembahasan}

\section{Implementasi Pelatihan Kewirausahaan}

Pelatihan kewirausahaan di PKBM Ummul Yatama yang mengintegrasikan pembelajaran dengan keterampilan berusaha sesuai sumber daya manusia dan potensi lokal yang tersedia dan dapat dioptimalkan di lingkungannya. Pelatihan dapat diartikan sejumlah pengajaran atau sederetan mata pelajaran yang diberikan kepada peserta didik di dalam suatu organisasi maupun di luar. Pelatihan merupakan proses penguasaan pengetahuan, sikap dan keterampilan tertentu atau suatu subject matter oleh peserta didik yang akan menimbulkan perbuatan atau perilaku. Kegiatan pelatihan diadakan untuk memenuhi suatu kebutuhan organisasi yang secara fungsional karena berbagai alasan seperti: struktur dan fungsi bagian-bagian ingin menyesuaikan beban dan kualitas tugasnya, sehingga personalianya memiliki kemampuan yang cukup baik dalam melaksanakan tugasnya secara optimal. Secara prinsipil pelatihan dilaksanakan untuk memenuhi suatu kebutuhan suatu organisasi (Kamil, 2010).

Pelatihan yang diselenggarakan oleh lembaga maupun organisasi ibaratnya sebuah modal yang bersifat internal dan tak ternilai harganya. Pelatihan merupakan suatu modal yang tidak terlihat (intelligible capital) yang nantinya diharapkan memiliki manfaat kembali dari hasil pelatihan tersebut (Marzuki, 2010). Melalui pelatihan, suatu organisasi akan mendapatkan manfaat berupa; efisiensi waktu, skill peserta pelatihan meningkat, dan produktifitas individunya meningkat. 
Training is a systematic restructuring of behaviour, attitude and skills through learning, education, instruction and planned experience. Training is designed to change or improve the behaviour of employees in the work place so as to stimulate efficiency. The cardinal purpose of training is to assist the organization achieves its short and long term objectives by adding value to its human capital. (Khan, et al., 2011)

Program pelatihan kewirausahaan ini pada dasarnya merupakan proses pembinaan dan pengembangan belajar dan berusaha yang menyentuh upaya pemberdayaan masyarakat. Pengembangan kewirausahaan tersebut dilaksanakan sesuai dengan potensi lokal dan sumber daya alam masyarakat setempat. Pemanfaatan dan pendayagunaan potensi lokal menjadi dasar pertimbangan pengembangan kewirausahaan sesuai dengan potensi, kearifan, keunggulan, kebiasaan, tradisi, dan adat istiadat yang berlaku di dalam lingkungan masyarakat. Gagasangagasan dari pengurus PKBM, pelatih dan warga belajar terkait dengan potensi lokal tersebut dapat diwujudkan ke program dan materi kewirausahaan yang dikembangkan di PKBM Ummul Yatama. Pelatihan kewirausahaan sebagai proses pemberdayaan ekonomi masyarakat yang menekankan kemampuan analisis kritis dalam mengidentifikasi masalah sosial dan ekonomi yang dihadapinya dan mengembangkan kompetensinya sebagai upaya perbaikan taraf kehidupannya. Esensi jiwa kewirausahaan merupakan jati diri seseorang yang dideskripsikan melalui sikap dan perilaku kreatif dan inovatif dalam menjalankan usahanya. Orang yang memiliki jiwa kewirausahaan adalah pelaku kewirausahaan yang lebih dikenal dengan sebutan wirausaha. Seorang wirausaha adalah orang yang melihat adanya peluang kemudian menciptakan sebuah organisasi untuk memanfaatkan peluang tersebut. Pengertian ini menekankan pada setiap orang yang memulai suatu bisnis yang baru. Proses kewirausahaan meliputi semua kegiatan fungsi dan tindakan untuk mengejar dan memanfaatkan peluang usaha dengan menciptakan suatu organisasi. (Alma, 2017).

Kewirausahaan adalah penerapan kreatifitas dan inovasi untuk memecahkan masalah dan upaya untuk memanfaatkan peluang yang dihadapi setiap hari. Kewirausahaan merupakan gabungan dari kreatifitas, inovasi dan keberanian menghadapi risiko yang dilakukan dengan kerja keras untuk membentuk dan memelihara usaha baru. The meaning of entrepreneurship is narrowed to the ability to create a business plan, to establish an enterprise, or to start a business. However, broadly defined, entrepreneurship means the ability to create wealth; it also refers to the dynamic interaction between the individual and any opportunities in a given environment marked by a high degree of complexity and uncertainty (Neck, Greene, 2011; Dutta et al., 2011). Kewirausahaan dalam arti sempit dapat didefinisikan sebagai kemampuan untuk membuat "rencana bisnis", untuk mendirikan perusahaan, atau untuk memulai bisnis. Kewirausahaan dalam arti yang luas dapat didefinisikan sebagai kemampuan untuk menciptakan kekayaan. Kewirausahaan mengacu pada interaksi dinamis antara individu dan setiap peluang usaha dalam lingkungan tertentu yang ditandai dengan tingkat kompleksitas dan ketidakpastian yang tinggi.

Pada tahap perencanaan pelatihan kewirausahaan pengurus PKBM; 1) melakukan identifikasi kebutuhan pelatihan, merumuskan dan menetapkan tujuan umum pelatihan pelatihan kewirausahaan; yaitu tercapainya pengembangan usaha produksi kerupuk bahan baku kerang dengan bahan baku berbagai jenis kerang di desa Mekarmaya. Selanjutnya menetapkan tujuan khusus pelatihan kewirausahaan; yaitu terbukanya peluang usaha pengolahan kerupuk kerang untuk meningkatkan pendapatan warga belajar Paket $C, 2$ ) menetapkan kurikulum dan bahan/materi pelatihan yang berisi teori dan praktek pelatihan keterampilan pengolahan kerupuk bahan baku kerang yang bertujuan meningkatkan pemahaman dan pengetahuan warga belajar dalam memproduksi kerupuk kerang yang layak memperoleh sertifikasi halal dan ijin PIRT. Melakulan pendampingan sikap dan perilaku kewirausahaan bagi warga belajar dalam mengembangkan usaha produksi kerupuk bahan baku kerang, 3) menetapkan sumber dana, yang berasal dari swadaya masyarakat yang dikelola PKBM Ummul Yatama, 4) menetapkan sumber belajar; yang berasal dari potensi lokal yang dapat disediakan bersama. Sumber belajar lainnya berupa informasi-informasi yang diberikan pihak PKBM, Dinas Kesehatan, dan Majelis Ulama Indonesia (MUI) Kabupaten Karawang selama melakasanakan pendampingan usaha, 5) menetapkan strategi pelatihan; yang digunakan dalam unit usaha kerupuk bahan baku kerang adalah pelatihan kewirausahaan partisipatif dengan metode bervariasi. Strategi pelaihan partisipatif merupakan proses pembelajaran yang melibatkan warga belajar pada tahap perencanaan, pelaksanaan dan penilaian. Pada tahap perencanaan pelatihan kewirausahaan dimulai oleh identifikasi kebutuhan belajar dan sumber belajar. Hal ini sejalan dengan hasil penelitian Hidayat (2017) yang 
menyimpulkan bahwa perencanaan pembelajaran dilakukan melalui identifikasi berbagai sumber daya dan dana pengembangan kewirausahaan. Implementasi pembelajaran menggunakan strategi sesuai kelompok usaha dengan berbagai metode pembelajaran partisipatif.

Identifikasi kebutuhan pelatihan pada tahap perencanaan pelatihan kewirausahaan dilaksanakan secara kelompok untuk memudahkan koordinasi dan pengelolaan usaha yang dilaksanakan warga belajar Paket C di PKBM Ummul Yatama. Identifikasi kebutuhan pelatihan ini dilakukan melalui Training Needs Assessment (TNA). Pribadi (2016) mengemukakan bahwa pada tahap TNA seorang perancang program pelatihan atau training designer perlu melakukan penilaian kebutuhan pelatihan yang dikenal dengan istilah Training Need Analysis atau TNA. Pada tahap TNA, perancang program pelatihan harus mengumpulkan data dan informasi yang terkait dengan masalah kinerja yang dihadapi oleh sebuah unit kerja dalam sebuah perusahaan. Hasil dari proses TNA menggambarkan masalahmasalah kinerja yang perlu dicari solusinya dan juga alternatif solusi yang diperlukan untuk mengatasi masalah yang telah diidentifikasi terkait dengan pelatihan kewirausahaan. Dalam hal ini perancang program pelatihan kewirausahaan di PKBM Ummul Yatama melakukan klarifikasi terhadap masalah kinerja warga belajar Paket $C$ dalam menjalankan usaha pengolahan dan pemasaran kerupuk kerang dan mengusulkan solusi-solusi yang akan digunakan dalam mengatasi masalah kinerja yang dihadapinya. TNA merupakan langkah awal untuk melaksanakan pelatihan kewirausahaan. TNA memainkan peranan yang penting dalam merancang dan menciptakan pelatihan kewirausahaan yang efektif dan efisien. Ada beberapa alasan TNA harus dilaksanakan sebelum mengembangkan program pelatihan. TNA plays an important role in designing and creating a successful and effective training. It is the key factor in determining whether the training achieved desired outcomes (Punia and Kant, 2013).

Pada tahap pelatihan kewirausahaan dilaksanakan pengorganisasian usaha pengolahan kerupuk kerang. Pengurus dan warga belajar Paket C mengorganisasikan usaha kerupuk kerang secara terstruktur dengan susunan organisasi tata kerja di PKBM Ummul Yatama. Pengorganisasian usaha diidentifikasi dan dianalisis sesuai dengan tujuan pengembangan kewirausahaan di PKBM Ummul Yatama. Pelatihan adalah proses memberikan keterampilan yang dibutuhkan untuk meningkatkan kinerja usaha warga belajar Paket $C$ sebagai peserta pelatihan. Pengorganisasian usaha diidentifikasi dan dianalisis sesuai dengan tujuan pengembangan kewirausahaan organisasi PKBM. The training needs of organization are defined based on the organization? Strategy, available resources (budget, time and human resource), and management support (Noe, 2010). Kegiatan pelatihan ditentukan berdasarkan kebutuhan organisasi. Strategi, sumber daya yang tersedia (anggaran, waktu dan sumber daya manusia), dan dukungan pengelolaan.

Pada tahap pelaksanaan usaha, pengelola melaksanakan tugas dan fungsi masing-masing. Pengelola PKBM Ummul Yatama, mempunyai tugas dan bertanggungjawab merencanakan pelatihan dengan mengidentifikasi kebutuhan pelatihan, perumusan tujuan pelatihan dan penyusunan program pelatihan kewirausahaan. Pada tahap pelaksanaan pelatihan kewirausahaan pengolahan kerupuk kerang warga belajar Paket $\mathrm{C}$ diberikan materi pelatihan kewirausahaan yang terdiri dari teori, praktik/ implementasi, dan pendampingan dengan mitra kerja dan mitra usaha PKBM sebagai sarana konsultasi bagi warga belajar Paket $C$. Pada tahap penilaian dilaksanakan untuk mengetahui peningkatan sikap dan pengetahuan kewirausahaan serta unjuk kerja usaha warga belajar dalam menjalankan program kewirauahaannya di PKBM Ummul Yatama.

Pelatihan merupakan proses memberikan keterampilan yang dibutuhkan untuk meningkatkan kinerja peserta pelatihan. Pelatihan kewirausahaan bertujuan mengembangkan, membangun, dan mempelajari teori-teori yang dirujuk kepada wirausahawan, penciptaan perusahaan, kontribusi terhadap pembangunan ekonomi, proses wirausaha dan perusahaan ukuran kecil dan menengah. Smith dan Ragan (2010) mengemukakan bahwa; "training are those instructional experiences that are focused upon individuals acquiring very specific skills that they will normally apply almost immediately". Program pelatihan dapat diartikan sebagai proses pengalaman pembelajaran yang memfokuskan pada upaya individu untuk memperoleh keterampilan tertentu yang dapat segera digunakan.

Tujuan pelaksanaan pelatihan kewirausahaan di PKBM Ummul Yatama adalah meningkat pengetahuan, keterampilan dan sikap kewirausahaan warga belajar dalam mengembangkan usahanya. Dalam upaya pengembangan kewirausahaan unit usaha kerupuk kerang, PKBM Ummul Yatama telah melakukan berbagai antara lain pengembangan kemitraan dengan pasar lokal, restoran dan toko-toko di sekitar Kabupaten 
Karawang. Dalam upaya meningkatkan produksi, upaya yang dilakukan dengan pengadaan mesin giling perbaikan kemasan. Pelatihan kewirausahaan bertujuan mengembangkan, membangun, dan mempelajari teori-teori yang dirujuk kepada wirausahawan, penciptaan perusahaan, kontribusi terhadap pembangunan ekonomi, proses wirausaha dan perusahaan ukuran kecil dan menengah. Tujuan pelaksanaan pelatihan kewirausahaan di PKBM Ummul Yatama adalah meningkat pengetahuan, keterampilan dan sikap kewirausahaan warga belajar dalam mengembangkan usahanya. Dalam upaya pengembangan kewirausahaan unit usaha kerupuk kerang, PKBM Ummul Yatama telah melakukan berbagai antara lain pengembangan kemitraan dengan pasar lokal, restoran dan toko-toko di sekitar Kabupaten Karawang.

Penilaian program pelatihan kewirausahaan bertujuan menganalisis: 1) dampak jangka panjang program, 2) outcome program, 3) output program, 4) proses program, dan 5) input program (Wijayanto, \& Prasetyo, 2018). Pada tahap penilaian usaha pengolahan usaha kerupuk kerang dilakukan secara rutin 1 (satu) bulan sekali oleh pengurus PKBM Ummul Yatama. Penilaian tersebut bertujuan untuk mengukur efektivitas pelaksanaan, faktor pendukung dan penghambat program unit usaha. Adanya penilaian juga membuka peluang jika ditemukan permasalahan untuk segera dicarikan solusinya. Penilaian terhadap kegiatan usaha pengolahan kerupuk kerang dilakukan dengan memonitor indikator keberhasilan yang telah ditetapkan dalam perencanaan program usaha. Indikator tersebut antara lain, kehadiran jumlah peserta, kuantitas dan kualitas produksi hasil usaha, jumlah pemasaran, jumlah pendapatan peserta, dan besar pendapatan yang diterima unit usaha. Sedang pengawasan dalam pengelolaan program usaha diadakan untuk mengontrol jalannya program pemberdayaan sesuai dengan perencanaan yang telah ditetapkan. Sedang pengawasan dalam pengelolaan program usaha diadakan untuk mengontrol jalannya program pemberdayaan sesuai dengan perencanaan yang telah ditetapkan. The main purposes of evaluating training are: 1) to determine whether the training meets its goals, 2) to identify the training program? Strengths and weaknesses, 3) to determine the trainees? reaction and response, 4) to define the financial benefits and the costs of training and 5) to help for better decision in choosing most appropriate training programs in the future (Noe, et al., 2011; Noe, 2010).

\section{Dampak Implementasi Pelatihan Kewirausahaan}

Tujuan utama pelatihan kewirausahaan di
PKBM Ummul Yatama adalah membentuk dan mengembangkan unit usaha rintisan kecil dan menengah yang sesuai dengan potensi yang dimiliki. Indikator keberhasilan peningkatan kompetensi kewirausahaan adalah bertambahnya pengetahuan, sikap, keterampilan, dan keberanian berusaha warga belajar Paket $\mathrm{C}$ secara mandiri baik perorangan ataupun merupakan bagian dari inkubator bisnis yang dikembangkan oleh PKBM sebagai upaya pemberdayaan masyarakat. Hal ini sejalan dengan pendapat Kindervatter (1979) yang mengemukakan beberapa strategi pemberdayaan masyarakat dalam organisasi sosial masyarakat, seperti PKBM: 1) berupaya untuk menumbuhkan kemampuan daerah melalui peningkatan organisasi serta menciptakan koalisi antar organisasi, 2) dimulai dari minat masyarakat dan berfokus pada masyarakat itu sendiri, 3) bersifat terbuka, tidak memiliki tujuan tertentu namun berupaya untuk mengaktifkan masyarakat untuk bekerja sama, 4) menekankan pada metode diskusi, prosedur demokrasi serta kerja keras. Fleksibilitas program pendidikan di jalur nonformal berkenaan dengan waktu dan lama belajar, usia peserta didik, bahan belajar, strategi, metode dan teknik, serta penilaian hasil belajar, memberikan peluang yang lebih besar ikut memberikan kontribusi dalam mengentaskan kemiskinan. Untuk itu, perlu ditingkatkan pendidikan berkelanjutan (contuining education) sebagai peran pendidikan nonformal dalam memberikan alternatif pemberdayaan masyarakat. Pemberdayaan masyarakat melalui kewirausahaan berbasis potensi alam setempat merupakan salah satu sarana dalam memenuhi kebutuhan warga belajar berupa pengetahuan dan keterampilan yang berkaitan bagi kehidupan sehingga warga belajar lebih siap menghadapi persaingan di era globalisasi yang disebabkan meningkatnya kualitas sumber daya manusia (Karwati, 2017). Pemberdayaan dalam bidang pendidikan, termasuk dalam pelatihan kewirausahaan berarti kemampuan dan keberanian untuk melakukan perubahan sosial, ekonomi, politik, maupun budaya untuk terus menerus memperbaiki kehidupan (Mardikanto \& Soebiato, 2015).

Dampak pelatihan kewirausahaan produksi kerupuk kerang telah berhasil meningkatkan kompetensi kewirausahaan warga belajar Paket $\mathrm{C}$ yang ditandai dengan bertambahnya pengetahuan, sikap, keterampilan, dan kemandirian usaha. Dampak pelatihan kewirausahaan kerupuk kerang terhadap pemberdayaan warga belajar Paket $C$ di PKBM Ummul Yatama adalah sebagai berikut; 1) membuka lapangan usaha bagi warga belajar Paket $\mathrm{C}$ memproduksi olahan 
kerupuk kerang untuk memperoleh penghasilan, 2) meningkatkan harga jual bahan baku kerupuk kerang dari warga belajar Paket $\mathrm{C}$ kepada pengepul lain, 3) meningkatkan pendapatan warga belajar hingga mencapai Rp. 500.000-800.000 perbulan, 4) peningkatan kapasitas diri melalui kemampuan kewirausahaan serta peningkatan keterampilan produksi dan budaya kerja yang baik. Dampak pelatihan dan pendampingan kewirausahaan adalah meningkatnya pemberdayaan ekonomi masyarakat di PKBM Ummul Yatama.

Hasil pelatihan kewirausahaan di PKBM Ummul Yatama telah sesuai standar kompetensi kewirausahaan, yaitu warga belajar Paket $C$ yang dapat; 1) mengidentifikasi peluang usaha yang sesuai kondisi alam, lingkungan dan peluang pasar, 2) merumuskan dan menyusun jenis usaha yang dikembangkan, 3) mampu memproduksi jenis usaha yang dikembangkan, 4) memasarkan hasil produksi, 5) mampu menghitung rugi/laba hasil usaha, 6) mengembangkan kemitraan usaha, dan 7) memelihara, meningkatkan, dan mengembangkan kemampuan kewirausahaan. Hasil pelatihan kewirausahaan diharapkan berdampak pada pemberdayaan ekonomi masyarakat. Dampak pelatihan kewirausahaan bagi warga belajar Paket $\mathrm{C}$ ini merupakan proses pemberdayaan masyarakat pada aspek peningkatan ekonomi keluarga. Strategi ini menyadari pentingnya kapasitas masyarakat untuk meningkatkan kemandirian dan kekuatan internal, melalui kesanggupan untuk melakukan kontrol internal atas sumber daya material dan nonmaterial yang penting melalui redistribusi modal atau kepemilikan (Korten, 1992) dalam Adimiharja \& Hikmat (2014). Pemberdayaan masyarakat merupakan kemampuan memahami potensi dan peluang dan masalah sosial yang bermuara pada kemampuan untuk menyelesaikan masalah kehidupan yang dihadapi. Karena itu, pemanfaatan potensi lokal yang dikembangkan dalam pendidikan kewirausahaan masyarakat menjadi penting. (Indrianti, dkk., 2020).

Implementasi pemberdayaan masyarakat atas prakarsa, inovasi, dan kreativitas masyarakat agak sulit diselenggarakan pada langkah awal program pembangunan. Keterlibatan beberapa pihak dari luar seperti badan pemerintah maupun swasta, lembaga swadaya masyarakat, dan lembaga penyandang dana/modal sangat diperlukan untuk mendorong partisipasi masyarakat melaksanakan pemberdayaan. Pemberdayaan adalah proses tindakan sosial dengan mengutamakan partisipasi individu-individu, lembagalembaga, organisasi-organisasi, dan seluruh lapisan masyarakat. Tujuannya adalah untuk meningkatnya pengawasan terhadap individu, kelompok, dan seluruh masyarakat, dalam mewujudkan pemerataan kesejahteraan yang berkeadilan sosial. Proses pemberdayaan masyarakat bersifat praktis dan memerlukan keikutsertaan seluruh masyarakat. Pemberdayaan masyarakat pada hakekatnya adalah serangkaian proses pemberian keberdayaan pada masyarakat agar memiliki kemampuan dan kekuatan mengidentifikasi berbagai permasalahan yang dihadapi, merumuskan, menemukan cara, dan mengambil keputusan untuk menyelesaikannya.

Cara kerja model intervensi pemberdayaan masyarakat untuk memecahkan masalah dalam mencapai tujuan tertentu adalah melalui penentuan kebutuhan dan masalah yang dihadapi masyarakat setempat, baik individual atau kelompok, menentukan prioritas masalah dan kebutuhan, membuat rencana pemenuhan kebutuhan dan masalah tersebut berdasarkan sumber-sumber potensial masyarakat setempat (sesuai dengan potensi lokal). Tetapi apabila sumber-sumber potensial tersebut tidak memadai, baru diperlukan bantuan tambahan dari berbagai pihak luar. Modal sosial sebagai potensi lokal adalah kunci untuk memobilisasi proyekproyek pemberdayaan masyarakat. Potensi lokal itu sendiri mempunyai beberapa kelemahan yaitu masyarakat tidak lagi memiliki kekuasaan penuh atau otonomi atas daerahnya untuk meningkatkan suatu kondisi masyarakat setempat yang sejahtera. Salah satu strategi pemberdayaan masyarakat yang dilakukan adalah melalui pelatihan pengembangan kewirausahaan pada program pendidikan masyarakat. Pemberdayaan masyarakat dalam konteks pendidikan masyarakat, lebih diutamakan pada sasaran utama yaitu terjadinya perubahan berpikir, bersikap dan berperilaku masyarakat menjadi rasional, dari perilaku malas menjadi rajin, dari sikap ketergantungan menjadi mandiri dalam aspek sosial dan ekomomi. Salah satu upaya pemberdayaan masyarakat bidang pendidikan masyarakat dapat dilaksanakan melalui program pelatihan kewirausahaan.

Strategi pemberdayaan melalui pelatihan kewirausahaan merupakan proses untuk menumbuhkan identitas pada loyalitas masyarakat lokal sebagai modal sosial. Pemberdayaan masyarakat dapat dipandang sebagai proses pengembangan masyarakat lokal yang ditujukan untuk menciptakan kemajuan sosial dan ekonomi bagi masyarakat melalui partisipasi aktif serta inisiatif anggota masyarakat itu sendiri. Masyarakat dipandang bukan sebagai sistem klien yang bermasalah melainkan sebagai masyarakat yang unik dan memiliki potensi, hanya saja potensi 
tersebut belum sepenuhnya dikembangkan (Suharto, 2014). Pemberdayaan masyarakat mencakup pengertian pembangunan masyarakat (community develpoment) dan pembangunan yang bertumpu pada manusia (community based develpoment). Strategi pembangunan masyarakat berbasis lokal merupakan strategi pemberdayaan masyarakat yang menggunakan pendekatan kewilayahan yang mengandalkan terutama sekali pada kebutuhan, seluruh potensi, dan pelaku lokal dari suatu daerah tertentu (locality) (Arsyad, dkk., 2011). Dalam perspektif sosial ekonomi pemberdayaan (empowerment) lebih dipandang sebagai upaya untuk memberi daya, dan bukan kekuasaan. Pemberdayaan masyarakat adalah memberi energy agar rakyat mampu bergerak secara mandiri, sehingga dengan demikian pemberdayaan tidak bersifat selamanya, melainkan sampai target mampu mandiri dan kemudian dilepas untuk mandiri. (Soleh, 2017).

Pemberdayaan merupakan konstruksi yang menghubungkan kekuatan dan kompetensi individu, sistem bantuan alam, dan perilaku proaktif dengan kebijakan dan perubahan sosial. Pemberdayaan masyarakat merupakan kontrol dan kepedulian pribadi terhadap pengaruh sosial, kekuatan kehidupan politik dan hak-hak hukum masyarakat. Pemberdayaan memiliki tiga tingkatan: pertama, pribadi sebagai pengalaman mendapatkan peningkatan kontrol dan pengaruh kehidupan sehari-hari terhadap partisipasi masyarakat. Kedua, kelompok yang melibatkan pengalaman bersama dan pengaruhnya terhadap upaya mereka sendiri. Ketiga, masyarakat yang pemanfaatan sumber daya dan strategi untuk meningkatkan kontrol masyarakat. Pemberdayaan masyarakat adalah upaya untuk membangun daya masyarakat itu sendiri, dengan mendorong, memotivasi dan membangkitkan kesadaran akan potensi yang dimilikinya serta berupaya untuk mengembangkannya. Selanjutnya, upaya tersebut diikuti dengan memperkuat potensi atau daya yang dimiliki oleh masyarakat itu sendiri. (Theresia, dkk., 2015).

\section{PENUTUP}

\section{Kesimpulan}

Program kewirausahaan pengolahan kerupuk kerang di PKBM Ummul Yatama dikelola melalui tahapan; perencanaan usaha produksi kerupuk kerang, pengelolaan kegiatan unit usaha kerupuk kerang, dan penilaian dan pengawasan usaha yang dilakukan secara rutin dan bertujuan untuk mengukur efektivitas pelaksanaan, faktor pendukung dan penghambat program unit usaha. Penilaian pelatihan kewirausahaan di PKBM Ummul Yatama dilakukan dengan menggunakan lembar observasi untuk mengevaluasi kehadiran jumlah warga belajar, kuantitas dan kualitas produksi hasil usaha pengolahan kerupuk kerang, jumlah pemasaran, jumlah pendapatan kelompok usaha, dan besar pendapatan yang diterima warga belajar Paket $\mathrm{C}$.

Program pelatihan kewirausahaan telah berhasil meningkatkan kompetensi kewirausahaan warga belajar Paket $\mathrm{C}$ yang ditandai dengan bertambahnya pengetahuan, sikap, keterampilan, dan kemandirian usaha. Pelatihan kewirausahaan pengolahan kerupuk kerang telah memberikan dampak terhadap warga belajar Paket $\mathrm{C}$ yang ditandai dengan; 1) terbukanya peluang usaha untuk mendapatkan penghasilan, 2) meningkatnya harga jual bahan baku kerupuk kerang, 3) meningkatnya pendapatan warga belajar,
4) meningkatnya keterampilan produksi kerupuk kerang dan budaya kerja yang baik. Pengurus dan warga belajar Paket $\mathrm{C}$ di PKBM berhasil memasarkan kerupuk kerang tersebut ke level yang lebih luas agar dikenal sebagai produk potensi lokal khas daerah Mekarmaya sebagai salah satu produk unggulan Kabupaten Karawang.

\section{Saran}

Berdasarkan hasil penelitian yang telah diperoleh, beberapa saran yang dapat diberikan adalah sebagai berikut; 1) Ketua PKBM Ummul Yatama dapat memberikan akses yang lebih luas untuk memberikan bantuan permodalan ke Bank bagi warga belajar Paket $\mathrm{C}$ dengan bunga pengembalian yang rendah untuk meningkatkan hasil produksinya, 2) Ketua PKBM Ummul Yatama dapat meningkatkan penyaluran hasil produksi ke pasaran yang lebih luas sehingga dapat lebih meningkatkan pemberdayaan warga belajar Paket $\mathrm{C}$, dan 3) Kepada Dinas Pendidikan dan Kebudayaan serta Dinas Perindustrian Kabupaten Karawang secara berkelanjutan memberikan pelatihan kewirausahaan untuk meningkatkan keterampilan warga belajar Paket $\mathrm{C}$ sesuai dengan perkembangan teknologi sehingga hasil produksi semakin meningkat dan pemasarannya semakin meluas. 


\section{DAFTAR PUSTAKA}

Adimiharja, K. dan Hikmat, H. (2014). Participatory Research Appraisal dalam Pelaksanaan Pengabdian kepada Masyarakat. Bandung: Humaniora Utama Press (HUP).

Alma, B. (2017). Kewirausahaan. Bandung: Alfabeta. Arsyad, L, Satriawan, E., Mulyo, J.H., dan Fitradi. A. (2011). Strategi Pembangunan Perdesaan Berbasis Lokal. Yogyakarta: UPP STIM YKPN.

Borchert, P.S. \& Cardozo R.N. (2010). Creative Destruction and Creative Combination, Journal of Applied Management and Entrepreneurship, 15,(2), 64-75.

Creswell, J. W. (2010). Research Design: Pendekatan Kualitatif, Kuantitatif, dan Mixed. Yogyakarta: PT Pustaka Pelajar.

Dick. W. Carey, L \& Carey J.O. (2015). The Systemic Design of Instruction. Ohio: Pearson.

Druker, P. (2015). Innovation and Entrepreneurship: Practice and principles. London: Routledge.

Dutta, D.K., Li, J., \& Merenda, M. (2011). Fostering entrepreneurship: impact of specialization and diversity in education. International Entrepreneurship Management Journal, 7 (2, 163-179. DOI: 10.1007/s11365-010-0151-2

Hidayat, D. (2017). Pengelolaan Pembelajaran Berbasis Kewirausahaan Masyarakat Program Kejar Paket C. Journal of Nonformal Education, 3 (1), 1-10. DOI: 10.15294/jne.v3i1.8727.

Hisrich, Peters, \& Shepherd. (2011). Entrepreneurship (6 ${ }^{\text {th }}$ ed.). New Delhi: Tata McGraw Hill.

Indrianti, D.T, Hartatik, S. \& Fajarwati. L. (2020). The Empowerment of Labour Women Picking Coffee Through the Education of Functional Literacy Based on Local Potentials. Journal of Nonformal Education, 6 (1), 61-58. DOI: 10.15294/jne. v6i1.21992.

Kamil, M. (2010). Model Pendidikan dan Pelatihan (Konsep dan Aplikasi). Bandung: Alfabeta.

Karwati, L. (2017). Pemberdayaan Perempuan melalui Pelatihan Kewirausahaan Berbasis Potensi Alam Setempat. Jurnal IImiah VISI PGTK PAUD dan DIKMAS, 12 (1), 45-58. DOI: 10.21009/ JIV.1201.5.

Kemendikbud. (2016). Model Pembelajaran Kewirausahaan (Terintegrasi Pendayagunaan Dana Sosial Masyarakat). Bandung: Kemendikbud Pusat Pengembangan Pendidikan Anak Usia Dini dan Pendidikan Masyarakat.

Khan, RA., Khan, FA., \& Khan, MF. (2011). Impact of Training and Development on Organizational
Performance, Global Journal of Management and Business Research, 11 (7), 62-68. Diakses melalui https://www.academia.edu/10235398/ Impact_of_Training_and_Development_ on_Organizational_Performance_Impact_ of_Training_and_Development_on_ Organizational_Performance

Kindervatter, S. (1979) Nonformal Education as an Empoworing Process. Massachusetts: Center for International Education University of Massachusetts.

Mardikanto, T \& Soebiato, P. (2015). Pemberdayaan Masyarakat dalam Perspektif Kebijakan Publik. Bandung: Alfabeta.

Marzuki, S. (2010). Pendidikan Nonformal; Dimensi dalam Keaksaraan Fungsional, Pelatihan dan Andragogi. Bandung: Rosdakarya

Nadler, L. (2012). Designing Training Programs: The Critical Events Model. Houston: Gulf Pub. Co.

Naranjo-Valencia J. C., Jiménez-Jiménez, D., \& Sanz-Valle R. (2011). Innovation or Imitation? The Role of Organizational Culture, Management Decision, 49 (1), 55-72.DOI: 10.1108/00251741111094437.

Nasution, S. (1988). Qualitative Naturalistic Research Methods. Bandung: Tarsito.

Neck, H.M., \& Greene, PG. (2011). Entrepreneurship Education: Known Worlds and New Frontiers. Journal of Small Business Management. 49 (1),55-70. DOI: 10.1111/j.1540627X.2010.00314.X.

Noe, R.A. (2010). Employee Training and Development. $5^{\text {th }}$ ed. New York: McGraw-Hill Irwin.

Noe, R.A., Hollenbeck, J.R., Gerhart, B. and Wright, P.M. (2011). Fundamentals of Human Resource Management. $4^{\text {th }}$ ed. New York: McGraw-Hill Irwin.

Pribadi, B.A. (2016). Desain dan Pengembangan Program Pelatihan Berbasis Kompetensi. Jakarta: Prenada Media Group.

Punia, B.K. and Kant, S. (2013). A Review of Factors Affecting Training Effectiveness Vis-À-Vis Managerial Implications and Future Research Directions. International Journal of Advanced Research in Management and Social Sciences, 2 (1), 151-164. Diakses melalui https://www. researchgate.net/publication/262375920_A_ Review_of_Factors_Affecting_Training_ Effectiveness_vis-a-vis_Managerial_ Implications_and_Future_Research_Directions 
Rahma, R.A, Zulkarnain, Desyanty, E.S., dan Wahyuni, S. (2019). The Role of Community Learning Center (CLC) in Providing Nonformal Education Services Based on Entrepreneurship. Journal of Nonformal Education, 5 (2), 109-116. DOI: 10.15294/jne.v5i2.19759

Smith, P.L \& Ragan, T.L. (2010). Instructional Design. USA: Willey Jossey-Bass Education.

Soleh, Ch. (2017). Dialektika Pembangunan dengan Pemberdayaan. Bandung: Fokusmedia.

Suharto, E. 2014. Membangun Masyarakat Memberdayakan Rakyat; Kajian Strategis Pembangunan Kesejahteraan Sosial \& Pekerjaan Sosial. Bandung: Refika ADITAMA.

Sulistiyani, T.A., (2017). Kemitraan dan Model-Model Pemberdayaan. Yogyakarta: Gava Media.
Theresia, A., Andini, K.S., Nugraha, P.G.P., Mardikanto, T. (2015). Pembangunan Berbasis Masyarakat. Bandung: Alfabeta.

Widodo, F. (2018). Evaluasi partisipasi masyarakat pada pembangunan infrastruktur dalam konteks pemberdayaan masyarakat. JPPM (Jurnal Pendidikan dan Pemberdayaan Masyarakat), 5 (2), 108-121. 10.21831/jppm.v5i2.15932

Wijayanto, A. \& Prasetyo, I. (2018). Evaluasi program pendidikan kewirausahaan masyarakat. JPPM (Jurnal Pendidikan dan Pemberdayaan Masyarakat), 5 (2), 96-10. DOI: 10.21831/jppm. v5i2.14999.

Yin, R.K. (2012). Studi Kasus: Desain dan Metode. Penerjemah Mudzakir, M.D. Jakarta: PT. RajaGrafindo Persada. 